\title{
Introduction of theoretical and methodological basis of agroclusters to the economy of Uzbekistan
}

\author{
$M$ Saidov $^{1, *}, A$ Abduvasikov $^{1}, D$ Mamadiyorov $^{1}$, and $D$ Saidova ${ }^{1}$ \\ ${ }^{1}$ Tashkent State Agrarian University, University str., 2, Tashkent province, Uzbekistan, 100140
}

\begin{abstract}
This article explores the theoretical issues of creating clusters, their tasks and capabilities, the impact of clusters on regional competitiveness. The internationally standardized experience in the creation and development of agricultural clusters were learned deeply in this article. The directions of the development of agricultural clusters in Uzbekistan are indicated.
\end{abstract}

\section{Introduction}

Improving the quality and competitiveness of products through the efficient use of processing capacity in the regions of the country can be achieved by increasing foreign exchange earnings to the country through their export, creating new jobs and increasing incomes $[1,3]$. At the same time, one of the urgent tasks is to move to a system-cluster system, which forms a chain of "production - purchase - storage and processing - export", which has proven itself in the world experience in the agricultural sector of our country [2, $8]$.

The need to harmonize the activities of all sectors of the agricultural sector of the country, that is, to solve problems in one direction, first of all, to develop a system of mutually beneficial economic relations between producers and processors on the basis of new modern methods of agribusiness, ie cluster approach occurred $[3,12]$. This is because the cluster approach to agro-industrial integration provides for a greater simplification of the organizational and economic relations between the agricultural sectors and the organization on the basis of mutual interest, that is, the interdependence of external and internal relations $[4,13,14,28]$.

In recent years, as a result of inefficient use of agricultural potential, the quality of agricultural products is not in demand, problems and shortcomings in the legal and economic relations between market entities engaged in their storage, processing and sale have negatively affected their efficiency and competitiveness. The research of this problem plays a large role in the oversight of the economic policy of the state, in improving the institutional framework of the agricultural sector, in promoting the development of more effective forms of integration.

\footnotetext{
* Corresponding author: $\underline{\text { m.h.saidov@yandex.com }}$
} 


\section{Materials and methods}

The concept of "cluster" in relation to industries and companies was introduced into the scientific turnover of the American business economist M. Porter in 1990 [15]. M.Porter, in the framework of his theory of national and regional competitiveness and competitive advantages, studied cluster problems [15-18]. Long before him, the processes of concentration of production and rational distribution were studied in the 1890-1950s by such researchers as A. Marshall, A.Lösch, W.Isard [6, 7, 11]. Works of outstanding economists on studying of the regional development issues and cluster strategies formed a theoretical and methodological basis of this research $[1,2,5,10]$. The theoretical base of the cluster concept was put at the beginning of the XIX century in works on economy of agglomeration of Von Thunen [24] and his fellow Weber A [26]. Cluster approach has the basis in works of A. Marshall and J. Schumpeter [9, 21-23, 27].

The concept of "cluster" can be used as an analysis of the object, as well as in the object of study. The cluster is supported by the object of support in the framework of the strategy of regional development, which is why the clusters increase productivity, innovation, competitiveness, profitability and efficiency in the region of firms [19, 20].

\section{Results and discussion}

From a theoretical and practical point of view, one of the main directions of increasing economic efficiency at the level of sectors and enterprises in a market economy is the adherence to the principles of regional development. Such an approach to agricultural development is based on the results of scientific research conducted by many agrarian economists. But the research done does not meet today's requirements mainly due to the fact that it was done during the planned economy period.

The globalization and deepening of integration processes in the world economy requires a comprehensive study of both the internal strengths and weaknesses of agribusiness, as well as its external opportunities and risks in the market. One of these opportunities is to organize an agro-industrial group on a cluster model $[24,25]$.

The cluster model (visual cluster - "growth together") is widely used in world practice as a tool to increase the competitiveness of an economic group, region, country as a whole. The main features of the cluster model are: the ability of the group to increase its share in foreign markets; availability of favorable conditions (raw materials, qualified personnel, infrastructure, training centers, scientific institutions, etc.) in the area; the breadth of opportunities for participants to participate effectively in the group in return for strong use of the group by the state $[4,27]$.

The organization of clusters in the processing industry creates a number of competitive advantages in the development of entrepreneurship and increase their competitiveness: firstly, to increase productivity of firms and industry enterprises in the cluster, secondly, increase opportunities for innovative development, thirdly expand new types of entrepreneurship and cluster activities.

Cluster effects are understood as the influence of participation in clusters on various result indicators of organizations and the cluster as a whole. Assessment of the degree of implementation of these competitive advantages is carried out within the framework of the cluster assessment methodology, which includes the principles, methods, indicators and criteria for evaluating effectiveness, as well as the logic of the evaluation process.

The main features of the cluster are reduced to the rule of four " $\mathrm{C}$ " [24] (Fig. 1):

1) the concentration of enterprises of one or related industries in one geographical point;

2) the competitiveness of their products; 
3) competition for winning and retaining customers;

4) cooperation with a high degree of development.

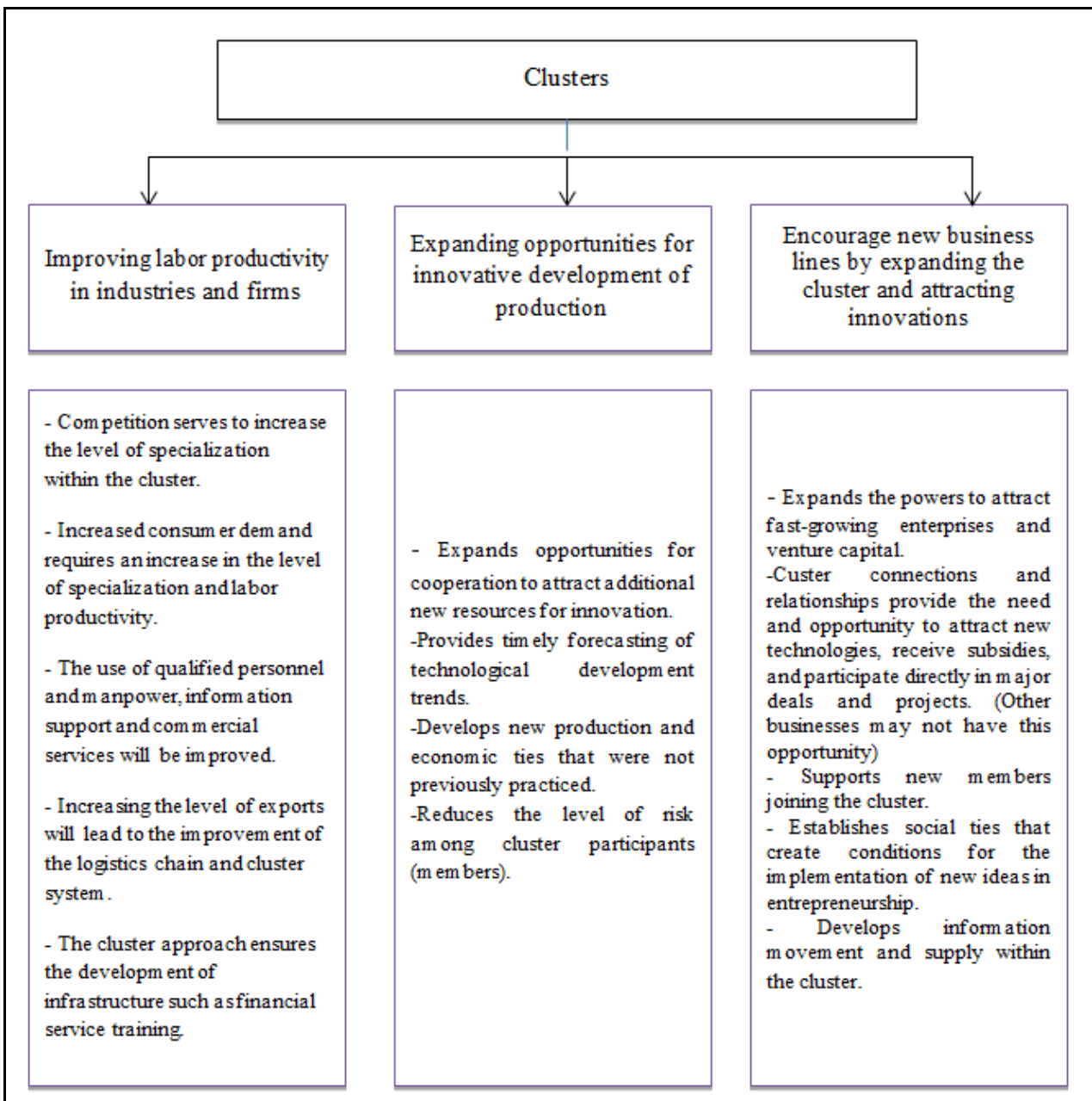

Fig. 1. Directions of clusters influencing the competitiveness of the economy.

When forming agro-industrial clusters by territorial specialization, which is most suitable for the agricultural sector, it is proposed to use the following criteria:

1) investment attractiveness of agribusiness in the region;

2) level of sustainability of productivity and productivity in crop production,

1. livestock and poultry;

3) the level of sustainability of production profitability for the main types of agricultural products;

4) level of sustainability of consumption of the main types of products [26].

Achieving this goal requires the involvement of companies, firms, enterprises and infrastructure entities with a certain performance in the cluster structure. The goal-oriented solution of mutually beneficial economic relations between the market participants of the cluster between producers and processors will be the basis for ensuring high efficiency of cluster activities, otherwise the ability to achieve the intended purpose of the cluster will be limited. 
According to economists, in the current context of accelerated globalization of the economy and the intensification of competition, the regions and territories that form the economy on the basis of a cluster approach are leading the way in economic development. Such a region and prospects determine the level of competitiveness of the state and national economy in which they are located. Regions that do not use the cluster approach to economic development, that is, those that use the traditional approach, are failing to achieve significant results and are becoming secondary areas.

The organization of agroclusters and the development of their activities lead to the following advantages:

- agroclusters not only provide access to foreign trade through the export of finished products, but also provide comprehensive assistance in the production of high-quality and high-quality products for imports, replacing imports using modern agricultural technologies for the domestic market;

- a relatively inexpensive and reliable raw material base will be created for many firms that are agrocluster enterprises and other group participants. The agrocluster, together with the suppliers of raw materials and products in all groups, prepares the desired product with the required quality and standards in accordance with the same technological regime (normative certificate and standard requirements, time schedules, etc. production discipline rules) in an integrated agrologistic system. will be able to deliver to markets;

- Creates a comprehensive database on access to foreign markets, along with the formation of agro-industrial associations, information and communication systems, modern warehouses and transport terminals and other infrastructure facilities, logistics centers, providing employment and allows you to choose the most effective marketing channel;

- on the basis of regulation of investment flows and priority development of all logistics links of the cluster (including infrastructure facilities), it will be possible to assess the effective use of natural resources (land, water, gas, etc.) and newly created technological and innovative potential;

- on the basis of regulation of investment flows and priority development of all logistics links of the cluster (including infrastructure facilities), it will be possible to assess the effective use of natural resources (land, water, gas, etc.) and newly created technological and innovative potential;

- Opportunity to provide targeted benefits to a group of enterprises that are important in the regional economy;

- The ability to quickly disseminate innovation news to all enterprises of the agro-cluster is also important for the development of innovative potential of the regions. The cluster development model allows the country, the region, and the group in particular, to raise their competitiveness indices. As a result, the possibility of attracting foreign investment to the region will increase;

- The ability to quickly disseminate innovation news to all enterprises of the agro-cluster is also important for the development of innovative potential of the regions. The cluster development model allows the country, the region, and the group in particular, to raise their competitiveness indices. As a result, the possibility of attracting foreign investment to the region will increase.

In USA, Germany, France, Italy, Bulgaria, Greece, the Netherlands, England, Switzerland, Denmark and other countries high-tech agro-clusters are widespread (Table 1). 
Table 1. Experience of foreign countries in the development of agro-industrial clusters [1-7, 9-12].

\begin{tabular}{|c|c|}
\hline Countries & Specific aspects \\
\hline USA & $\begin{array}{l}\text { High-tech agro-industrial clusters are common in all states of the United States. } \\
\text { Large agro-clusters are located in Washington, Oklahoma, Louisiana, and wine } \\
\text { production in California. High-performance clusters can also be seen in Silicon } \\
\text { Valley's Information Technology clusters and Hollywood's Kinofication clusters. } \\
\text { There are } 380 \text { clusters in the United States, and the share of clusters in GDP is } \\
61.4 \% \text {. }\end{array}$ \\
\hline France & $\begin{array}{l}\text { In France, the Agropolis Association was established in Montpellier in } 1986 \text { to } \\
\text { coordinate the activities of agricultural enterprises, educational and research } \\
\text { institutions in order to enter the European and world markets of technology and } \\
\text { innovation. }\end{array}$ \\
\hline UK & $\begin{array}{l}\text { Since 2001, the Stockbridge Technology Center, an innovative agro-industrial } \\
\text { cluster in the UK, has been conducting research and training programs in indoor } \\
\text { agriculture, horticulture and vegetable growing. The center has modern } \\
\text { greenhouses and high-tech laboratories on } 70 \text { hectares of irrigated land, } 40 \\
\text { computer-controlled areas ranging from } 12 \text { to } 1,000 \text { square meters. }\end{array}$ \\
\hline Austria & $\begin{array}{l}\text { In Austria, too, more emphasis is being placed on the specialization of clusters, the } \\
\text { promotion of interaction between agro-industrial and research enterprises, the } \\
\text { reduction of barriers to the management of innovation programs, and the formation } \\
\text { of competitive centers. }\end{array}$ \\
\hline Denmark & $\begin{array}{l}\text { In Danish agriculture, animal husbandry is more important than agriculture, } \\
\text { agricultural products are used more for feed, the role of dairy in animal husbandry } \\
\text { is higher than in the meat sector, so dairy clusters (for example, the well-known } \\
\text { "Molochnaya vertical" cluster) are widespread. }\end{array}$ \\
\hline Russia & $\begin{array}{l}\text { In Russia, too, in all sectors of the economy, sh.j. In the agro-industrial complex, } \\
\text { more than } 200 \text { projects on the formation and development of clusters are being } \\
\text { implemented. The "Concept for the Development of Territorial-Industrial Clusters" } \\
\text { adopted by the Ministry of Economic Development in } 2008 \text { consists of three } \\
\text { blocks: promoting the institutional development of clusters; increase the } \\
\text { competitiveness of cluster participants; creating favorable conditions for the } \\
\text { development of clusters. In the cluster "Biocomplex" of Tomsk region (new crop } \\
\text { of wheat and soft and osty varieties resistant to fungal diseases were created, } \\
\text { followed by the creation of "AgroPARK", which includes deep grain processing, } \\
\text { biotechnology, petrochemical production), cluster "Baltika" in Tula region } \\
\text { (scientific - Achieved the cultivation of } 17 \text { varieties of oats for brewing beer } \\
\text { (included in the register of achievements of Russia) on } 672 \text { experimental sites of } \\
\text { the research station, In the Kemerovo region, the agro-industrial brand } \\
\text { "KalinaMalina" (with } 7 \text { shops and } 40 \text { farmers), in the Vologda region, the cluster } \\
\text { "Biotechnology" (with OAO "FosAGRO"), etc. the process of establishing similar } \\
\text { modern agro-clusters in the regions has accelerated considerably. }\end{array}$ \\
\hline
\end{tabular}

According to foreign economists, the need to ensure the principles of priority and equality in relations is associated with limited resources, globalization processes, the state of affairs in domestic and foreign markets, specific aspects of global and national economic development. In turn, such situations require rapid adaptation to changes in domestic and foreign markets. Public-private partnerships expand opportunities to adapt to such changes. This is because the state and business entities establish partnerships with the feeling that they can solve the current situation in economic and social life in an interconnected way. It can be said that the above circumstances require a wider range of active state intervention in the activities of economic entities, and this intervention is based on priority and mutual equality. In general, the system of public-private partnership ensures the supremacy of 
public policy in various sectors of the economy, while ensuring the participation of the state in economic processes.

In order to produce high value-added products in Uzbekistan, increase exports, develop decommissioned and dry lands, increase the planting of export-oriented agricultural crops on cotton, cereals, as well as the effective use of orchards, vineyards and greenhouses, various specialized clusters, agriculture special attention was paid to the establishment of associations (cooperatives) and their priority development. In 2019, 77 cotton and textile clusters were launched (in 2018: 16) and 552.5 thousand hectares and 125 thousand hectares allocated to them on the basis of contracts concluded with them and more than 16.0 thousand farms, for a total of 677.5 thousand 2.4 million tons $(100.0 \%)$ of raw cotton were produced per hectare.

The cluster method, which has been successfully tested in the cotton sector, is being widely introduced in other sectors of agriculture in Uzbekistan. In 2019, the number of fruit and vegetable clusters was increased to 66 and a total of 18.9 thousand hectares of land were allocated to them. Initiators have also been identified for the establishment of clusters in grain (145), rice (33) and seed, and organizational measures are being taken to establish their activities.

In order to produce high-quality and export-oriented products, to process them and direct them to the markets of developed countries, serious attention is paid to expanding the geography of exports. At the same time, a total of 2 million 107.6 thousand tons of products were processed by 597 processing enterprises on 133 projects with a capacity of 258 thousand tons.

In 2019 , a total of 1.4 million tons (113\% more than in 2018) of products worth $\$ 1$ billion 250.4 million (140\%) (including vegetables: 589.4 thousand tons, $134 \%$ (worth $\$$ 266.6 million) ; fruit: 296.1 thousand tons, $119 \%$ ( $\$ 308.0$ million); melons: 38.7 thousand tons, $116 \%$ ( $\$ 15.5$ million); grapes: 187.8 thousand tons, $91 \%$ (221, $\$ 1$ million); legumes and oilseeds: 170.8 thousand tons, $84 \%$ (\$ 186.8 million); dried fruits and vegetables: 121.3 thousand tons, $104 \%$ ( $\$ 205.9$ million) and seedlings: 3.1 thousand tons ( $\$ 46.6$ million) were exported to the markets of Slovakia, Brazil, Algeria, Israel, Hungary, Hong Kong, Kuwait, Greece, Mongolia, Morocco, Australia, Bosnia and Herzegovina, France, Canada and Qatar.

\section{Conclusion}

The main directions of promoting the effective functioning of agro-clusters in Uzbekistan are:

- In order to form the innovative activity of enterprises according to the cluster model and adapt and adapt to new conditions, it is necessary to develop group relations based on modern corporate governance mechanisms within the cluster, taking into account the interests of participants, improving internal and external regulations;

- It is necessary to develop mechanisms for local authorities to have the necessary beneficial impact on the innovative activities of enterprises participating in the cluster and to identify ways to implement them in the context of the region;

- In order to provide the participants of the agro-cluster with the necessary information, it is necessary to create a single digital and identifiable database on effective corporate governance, first of all, to establish mutually beneficial business relations between the cluster and the participant-firm within this group;

- The concept of general quality management provides a reliable analysis of the current state of its resources and infrastructure, forecasting tools for the near and long term to develop a logistics strategy for each cluster in accordance with the requirements of Total 
Quality Management (TQM ISO-9000/2010) and the rules of modern integrated logistics system creation required;

- For the effective functioning of agro-clusters it is necessary to take measures to organize and improve the system of continuous training, retraining and advanced training of specialists;

-It has not been long since many clusters were established and started operating in Uzbekistan. In this regard, the results of their activities have not yet been fully formed, and we consider it expedient to develop a system of indicators for evaluating the effectiveness of clusters.

\section{References}

1. Z. Abidin, N. M. Kamal, K. Jusoff, International Journal of Economics and Finance, 1(1), 150-161 (2014)

2. M. Afanasyev, L. Myasnikova, Economy questions, 4, 75-86 (2005)

3. R. Baptista, The Dynamics of Industrial Clustering: International Comparisons in Computing and Biotechnology Oxford University Press Oxford, 185 (1998)

4. E. Bergman, E. Feser, Industrial and Regional Clusters: Concepts and Comparative Applications Regional Research Institute, West Virginia University, 174 (1999)

5. E. Dahmen, Entrepreneurial Activity and the Development of Swedish Industry, Stockholm, Sweden, 251 (1990)

6. W. Isard, Introduction to Regional Science, 410 (1975)

7. W. Isard, Methods of Regional Analysis: an Introduction to Regional Science, 660 (1990)

8. T. Y. Kovalyova, Bulletin of Perm University, 4(11), 31 (2011)

9. C. Lin, Y. Ma, P. Malatesta, Y. Xuan, Journal of Financial Economics, 109(2), 517534 (2013)

10. K. G. Mäler, F. Maler, Environmental economics: A theoretical inquiry, Routledge 241 (2013)

11. A. A. Migranyan, Problems of the modern economy, 1(21), 114-121 (2007)

12. T. V. Mirolyubov, Bulletin of Perm University, 3, 36-48 (2010)

13. N. A. Neustroyeva, Russian business, 10(232), 114-125 (2013)

14. M. V. Nikolaev, I. E. Egorova, Problems of the modern economy, 3/4(19/20), 117-128 (2006)

15. M. Porter, The Competitive Advantage of Nations, 371 (Free Press, New York, 1990)

16. M. Porter, Harvard Business Review, 77-90 (1998)

17. M. Porter, Competition, 199 (Williams publishing house, 2005)

18. G. Rosenfeld, European Planning Studies, 5, 3-23 (1995)

19. P. Rouvinen, P. Ylä-Antitila, Boosting Innovation: The Cluster Approach, 388 (OECD, Paris, 1998)

20. D. N. Saidova, SH. S. Dehkanova, South Asian Journal of Marketing \& Management, 9(8), 47-54 (2019)

21. J. A. Schumpeter, The Theory of Economic Development, 256 (New York: Oxford University, 1934) 
22. P. Swann, The Dynamics of Industrial Clustering: International Comparisons in Computing and Biotechnology, 544 (Oxford University Press, Oxford, 1998)

23. T. V. Tsikhan, Theory and practice of management, 65 (2003).

24. J. H. Von Thünen, Isolated state: An English edition of Der isolierte Staat, Pergamon 264 (1966)

25. L. Walras, Elements of pure economics, 215 (2013)

26. A. Weber, Über den standort der industrien, JCB Mohr, 187 (1999) (in German)

27. S. Winters, R. L. Kool, N. S. Klazinga, R. Huijsman, International Journal for Quality in Health Care, 8, 57-71 (2014)

28. U. Mukhtorov, In E3S Web of Conferences, 244, 03013 (2021) 